\title{
THE EVALUATION OF THE EFFECTIVENESS OF THE ENVIRONMENTAL MANAGEMENT INSTRUMENTS OF LATVIA
}

\author{
Lilita Ābele $^{1}$, Māra Zeltiṇa ${ }^{2}$, Ligita Šimanskiene ${ }^{3}$, Darius Burgis ${ }^{4}$ \\ ${ }^{1}$ University of Liepaja, Latvia, lilita.abele@liepu.lv \\ ${ }^{2}$ University of Liepaja, Latvia, mara.zeltina@liepu.lv \\ ${ }^{3}$ University of Klaipeda, Lithuania, ligita_simanskiene@yahoo.com \\ ${ }^{4}$ University of Klaipeda, Lithuania, darius@itinovacijos.lt \\ crossref $\mathrm{http}: / / \mathrm{dx}$.doi.org/10.5755/j01.em.17.3.2117
}

\begin{abstract}
Research problem: The ambiguity and lack of data for application of indicators of environmental management burden the improvement of support instrument system and the development of sustainability of borderland regions.

The aim of research: investigate the place of environment aspect in the development of enterprises in Kurzeme. Based on the obtained results, develop suggestions for the environmental management indicators by the use of which there could be controlled the effectiveness of the use of entrepreneurship support instruments and the environmental results of the enterprises. Practical research consists of inquiry - internet survey, where questionnaire form was located into internet page www.apklausa.lt. Information was gained from 150 entrepreneurs in the Kurzeme from different business branches.

Conclusions: entrepreneurs have different attitude towards the objectives of entrepreneurship support instrument usage and the place of nature resource tax in the decision making on company development.

As the result of the research there is developed the system of indicators of environmental management for entrepreneurs, policy- makers and legislation creators at the level of the state and municipalities.

Keywords: environmental management tools, business environment, environmental aspects, environmental management indicators.

JEL Classification: Q580.
\end{abstract}

\section{Introduction}

For the first time the necessity of environmental protection is stated in Hammurabi's , king of Babylon (Yale Law School, Doc. Collection, 2011), code of statutes, where is mentioned the law of forest protection as well as protected plants (for example: The Code of Hammurabi Article 56, without the notice of the owner of the garden, cuts down a tree in the garden, he has to pay a half of mina in cash and other). Concept of "sustainable development" has formed from ideas of nature's protection, conservation and rational usage of natural resources. One of the most essential development stages of the conception is the book written by Rachel Carson "Silent spring” and Gro Bruntland's UNO report (1987).

In the world and EU there are drafted several methodologies, in order to estimate sustainable development of a country, region and an enterprise. Sustainable Society Index (SSI), for the first time used in Year 2006, is one of the methods continuously developing on a regular basis. This index is determined by using 24 economic, environmental and welfare indicators that are sorted in 8 categories (Sustainable Society Foundation, Data Details SSI, 2010). The assessment results of Year 2010 shows that, within 151 countries, Latvia takes the $6^{\text {th }}$ place, but Lithuania- $17^{\text {th }}$ place, which is a positive result. Analyzing the assessment of Latvia and Lithuania in economical categories (material consumption, organic "framing", genuine savings, gross domestic product, employment, public debt), the performance noticeably falls behind other countries, who are included in "Top 20 countries" (Sustainable Society Foundation, Top 20-Bottom 20, 2012). This indicates the need for the management to pay more attention to a sustainable development of business, by developing methodologies for assessment of regional sustainability. World's leading enterprises sustainability considers as a driving force of innovations and as an opportunity for new market niches.

\section{Sustainable business promotion tools}

The analyses of environmental management instruments suggest improving determination and regulation methods of environmental economic effectiveness. The disposable resources of the governments concerning promotion methods of sustainable business can be divided in five main groups: institutional, regulatory, economical, voluntary and educational (Hackett, 2006): 
Institutional- assignation of public good's ownership to another market player, reduction of transaction payment, provision of access to information.

Regulatory- laws, rules or standards, which determine requirements for manufacturing process, goods or contamination, as well as quotas, bans, non-tradable licenses.

Economical- market oriented instruments are divided as following:

1. In an existing market- rates, taxes, payments, subsidies of goods, subsidies for actions.

2. In new market- tradable licenses of contamination, tradable licenses of natural resource extraction, compensatory mechanisms.

3. Other instruments- insurance, mechanisms of financing and full cost coverage.

Voluntary- management instruments in business are introduction of certified environmental management system, eco-design and eco-branding.

Educational- state's focused action to educate society's different age groups at an appropriate level about the field of environment. The diversity of sustainable business promotion instruments allows the entrepreneur to choose a support instrument for the improvement of environmental performance, in its turn, the governments maintaining the state's sustainable development, determine system of support instruments, paying special attention to economical and regulatory (Kosonen, Nicodèm,2009) instrument mutual relations and usage.

Development of sustainable business affects not only the management instruments, but also the location of the enterprise, the development level of the corresponding region and specific features of a region. There are quite large differences between frontier territories. In EU frontier territories- Estonia's and Lithuania's frontier does not have such explicit "outskirts" effect as it is in Eastern frontier.

In order to perform a business development analyses and determine what kind of changes are necessary for environmental management instrument development, improvement and provision of effective action, it is essential to develop/ apply appropriate instrument, by which evaluate the sustainability of an enterprise.

In this context, in Latvia constantly popularity gains assessment, as a result the index of enterprise's sustainability is determined. By using the determination method of business sustainability index, the enterprise's performance in all aspects of corporate responsibility is estimated: environment, market relations, working environment and the responsibility to the society. This assessment is:

1. Voluntary, based on the self-appraisal of the enterprise, confirmed by references from publications or other proof (checked by the Panel of Experts);

2. International, subjacent methodology, based on the experience of the most important global indexDow Jones Sustainability Index and Business in the Community CR Index, and corporative responsibility standards ISO 2600 and G3 guideline requirements of Global Reporting Initiative (GRI), (Strategic management tool, Sustainability Index, Latvia, 2011).

At the same time these methods are appropriate for Latvia's socio-economic conditions.

The index of enterprise's sustainability is an essential strategic management instrument, which provides an enterprise the opportunity to follow after the dynamics of performance, as well as to compare the performance with other enterprises. However, it is important to apply an instrument for the determination of enterprise's sustainability, which can be used apart from the communication and self-identification of enterprise, concerning the affiliation to innovative, sustainable or green product manufacturing enterprise groups. The method used for the estimation of enterprise's sustainability must be capable to provide a high confidence level of results and ensure the opportunity to follow development dynamics of sustainable business, compare development in regions and offer suggestions for hedging business support instrument effectiveness.

\section{Research methodology}

The research was carried out in period from May till August (2011), with the help of Internet surveying 150 enterprises in the Kurzeme (apklausa.lt/private/forms/survey-of business-support-inlithuanian-latvian-crosborder-region,2011) the amount of enterprises has been chosen according to the amount of registered enterprises (Latvia, year 2009). The practical research was applied, in the process of "Formation of methodological framework of regional business growth promotion (LT-LV)" project, in the summer of 2011, by carrying out a survey for regional enterprises. Till May, year 2011, there were no data about year 2010. In the Table 1 is distinguished the structure of Kurzeme enterprise fields. 
Table 1. In Kurzeme surveyed enterprise field structure, year 2011

\begin{tabular}{|l|r|r|r|}
\hline \multicolumn{1}{|c|}{ Field } & $\begin{array}{c}\text { Amount of } \\
\text { organizations }\end{array}$ & \multicolumn{1}{c|}{ \% } & Surveyed \\
\hline Agriculture, forestry and fishery & 5868 & 0,362939139 & $\mathbf{5 4}$ \\
\hline Industry & 1057 & 0,065376051 & $\mathbf{1 0}$ \\
\hline Environment and power & 99 & 0,006123206 & $\mathbf{1}$ \\
\hline Construction & 805 & 0,049789708 & $\mathbf{7}$ \\
\hline Trade & 2339 & 0,144668481 & $\mathbf{2 2}$ \\
\hline Services & 3476 & 0,214992578 & $\mathbf{3 2}$ \\
\hline Finance and insurance & 166 & 0,010267194 & $\mathbf{2}$ \\
\hline Education & 237 & 0,014658585 & $\mathbf{2}$ \\
\hline Health and social work & 577 & 0,035687778 & $\mathbf{5}$ \\
\hline Other & 1544 & 0,095497279 & $\mathbf{1 4}$ \\
\hline In total & $\mathbf{1 6 1 6 8}$ & $\mathbf{1}$ & $\mathbf{1 5 0}$ \\
\hline
\end{tabular}

By analyzing the results of survey, it can be concluded that in Kurzeme the most popular activity fields are: agriculture, forestry and fishery, service, trade, where operates small (micro) and average small enterprises with around 50 employees and the turnover up to 1.4 million LVL, and with the duration period longer than 7 years- $58 \%$.

\section{Effectiveness assessment of used support tools}

All fields affects the environment, though, most explicit it is for agriculture, forestry and fishery, hence we tried to find out, which of the available business support resources could serve as environment management instruments, enterprises even without realizing it.

Table 2. The usage of business support instruments in Kurzeme, year 2011

\begin{tabular}{|c|c|c|}
\hline Answers & $\begin{array}{l}\text { Frequency of } \\
\text { mention }\end{array}$ & $\begin{array}{l}\text { Percentage out of frequency of } \\
\text { mention }\end{array}$ \\
\hline Free economic zones & 2 & $\| 0.7 \%$ \\
\hline Guaranties & 4 & $\| 1.3 \%$ \\
\hline Other & 6 & $2.0 \%$ \\
\hline Informative support & 12 & $4.0 \%$ \\
\hline Rental allowance & 14 & $4.7 \%$ \\
\hline Tax relief & 15 & $5.1 \%$ \\
\hline Subsidies & 28 & ㅁ.4\% \\
\hline Consultations & 30 & $10.1 \%$ \\
\hline $\begin{array}{l}\text { Does not use any business } \\
\text { support instruments }\end{array}$ & 36 & $\square 12.1 \%$ \\
\hline $\begin{array}{l}\text { Trainings, courses of study, } \\
\text { seminaries }\end{array}$ & 41 & $13.8 \%$ \\
\hline EU Structural Funds & 49 & $16.5 \%$ \\
\hline Loans & 60 & $\mid 20.2 \%$ \\
\hline
\end{tabular}

Most frequently used support instruments are loans, EU Structural Funds, and trainings, courses of study, seminaries and consultations. A considerable fact- $12 \%$ of respondents do not use any support resources (Table 2.). In order to estimate necessity and effectiveness of most frequently used support instruments, entrepreneurs evaluated it in scale from "very effective" to "not effective". 


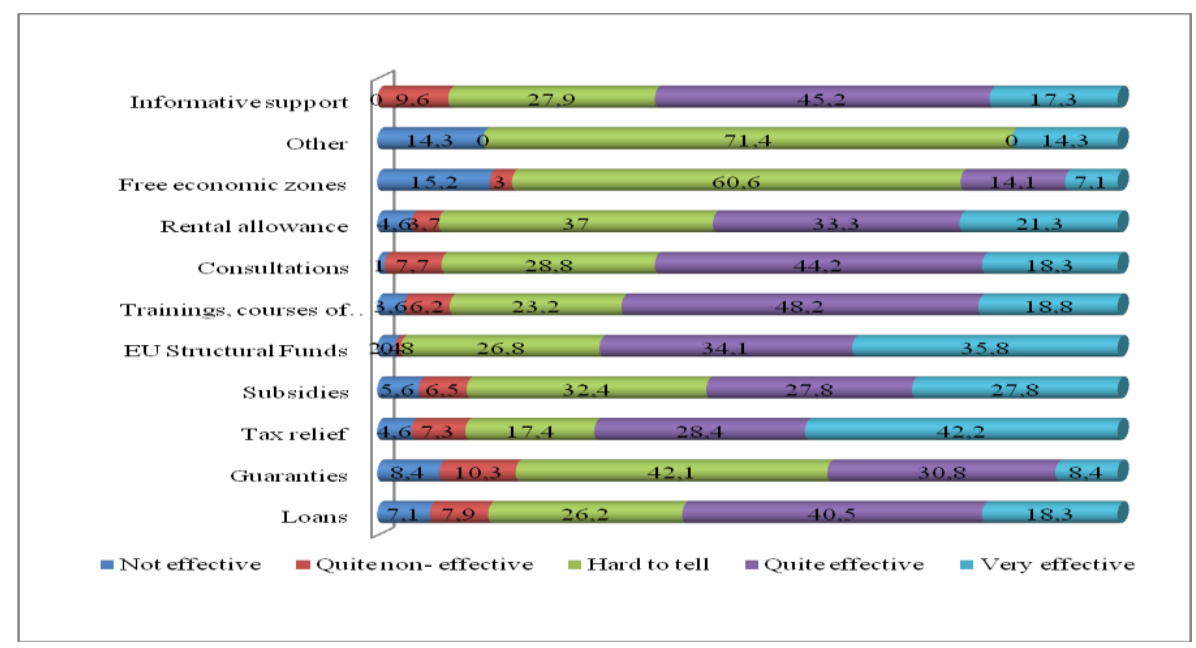

Figure 1. Effectiveness assessment of support instruments in Kurzeme, year 2012

As most necessary and effective business support instruments were mentioned- EU Structural Funds, followed by trainings, courses of study, seminaries (Figure 1.). The most frequently used support instrument is loans, entrepreneurs do not consider as the most necessary and effective. With a positive mark can be estimated the fact that for the business development entrepreneurs uses not only material resources as, for example, possibilities of loans and EU Structural Funds, but also different trainings, courses of study, seminaries and consultations, which approves entrepreneur willingness to acquire new knowledge. This support instrument could serve as an effective environment's management instrument, if it could be identified as one and purposefully developed. The survey analysis shows that, the bigger organization's annual turnover, the frequently organizations uses the support of EU Structural Funds, in order to promote own business development. Also different consultations are used by organizations with greater annual turnover. New organizations, with the duration of 1 year, mainly do not apply any business support instruments, in some cases either trainings, courses of study, seminaries or consultations are used. In its turn, the longer the duration of an organization, the varied business support resources are applied, in order to promote successful development of an organization. An interesting fact, the longer an organization operates, the frequently as a business support instrument EU Structural Funds are used. It can be concluded that the longer an organization operates, the bigger experience it gets, the more frequently it seeks new opportunities for development.

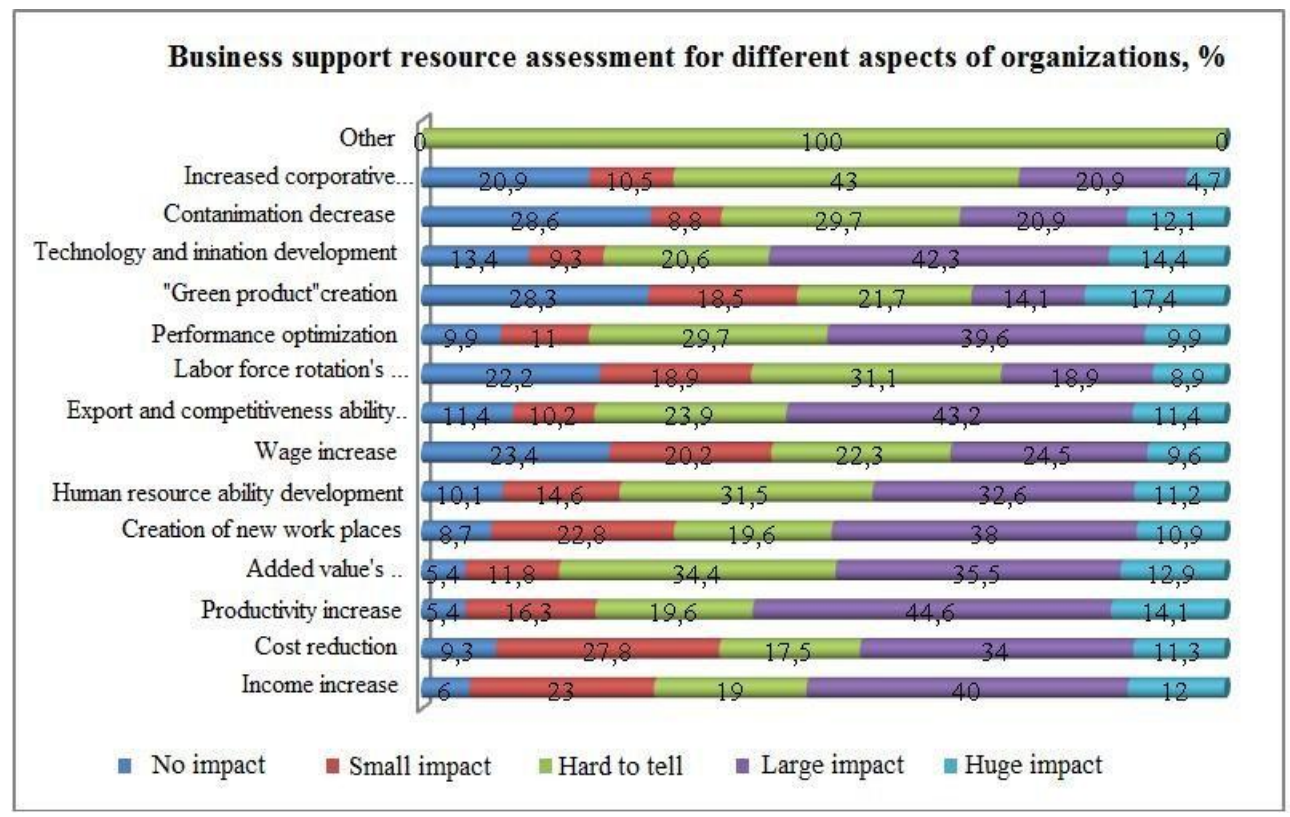

Figure 2. Business support resource assessment for different aspects of organizations in Kurzeme, year 2011 
In order to ascertain, how the applied business support resources have influenced different organization's aspects, in the survey period entrepreneurs were asked to evaluate them in the categories from "huge impact" to "no impact" (Figure 2.).

Five current aspects, on which applied support resources left the largest impact, are:

1. Productivity increase $(58.7 \%)$

2. Technology and innovation development (56.7\%)

3. Increase of export and competitiveness ability (54.6\%)

4. Income increase (52\%)

5. Performance optimization (49.5\%)

In order to determine those business support instruments, who are used for the hedging of sustainability, multi- factor analysis was applied. The essence of factor analysis is that on the basis of the indicator set, which describes researched economic phenomena, it is possible to distribute a small amount of complex factors, which cannot be observed directly; they are not correlatively related and describe the general structure of initial factor system. Aim of factor analysis - to explain the found correlation, by detecting factors, which determine this correlation.

As it is visible in the analyses Table 3. of statistical data, three support instrument factor groups can be distinguished (factor coherence shown in bold).

Group 1 receives rental allowance and other types- trainings, courses of study, seminary, consultations, informative support, which can be determined as informational and educational support for business.

Group 2 benefits subsidies, EU Structural Fund resources and operates in free economic zones. This group can be describes as business group of preferential conditions.

Group 3 collects guaranties and tax reliefs, as well as loans (negative correlation). It can be defined as financial help for enterprises.

All business factors can be grouped as following:

1. informational and educational support,

2. provision of preferential conditions,

3. financial support.

Table 3. The evaluation of the correlation factor's supporting entrepreneurship

\begin{tabular}{|l|l|l|l|}
\hline \multicolumn{1}{|c|}{ Business support types } & \multicolumn{3}{c|}{ Components } \\
\cline { 2 - 4 } & \multicolumn{1}{c|}{1} & 2 & \multicolumn{1}{c|}{3} \\
\hline Loans &, 002 &,- 025 & $\mathbf{- , 8 0 2}$ \\
Guaranties &,- 073 &, 572 & $\mathbf{, 6 6 9}$ \\
Tax relief &, 458 &, 016 & $\mathbf{, 7 0 0}$ \\
Subsidies &, 021 & $\mathbf{, 9 0 9}$ &,- 249 \\
EU Structural funds &,- 045 & $\mathbf{, 7 9 5}$ &, 441 \\
Trainings, courses of study, seminaries & $\mathbf{, 9 4 0}$ &, 061 &,- 118 \\
Consultations & $\mathbf{, 9 3 5}$ &, 063 &,- 128 \\
Informative support & $\mathbf{, 8 9 2}$ &, 033 &, 282 \\
Rental allowance & $\mathbf{, 8 5 2}$ &, 059 &, 314 \\
Free economic zones &, 469 & $\mathbf{, 6 8 4}$ &, 192 \\
\hline
\end{tabular}

Extraction method: Principial component anliysis.

Rothation method: Warimax with Kaiser normalization.

Rotation converged in 5 iterations.

As it is visible within the factor groups exists a very strong coherence, all component highest limit is within the scope from 0,669 to 0,940 (Figure 3.). 


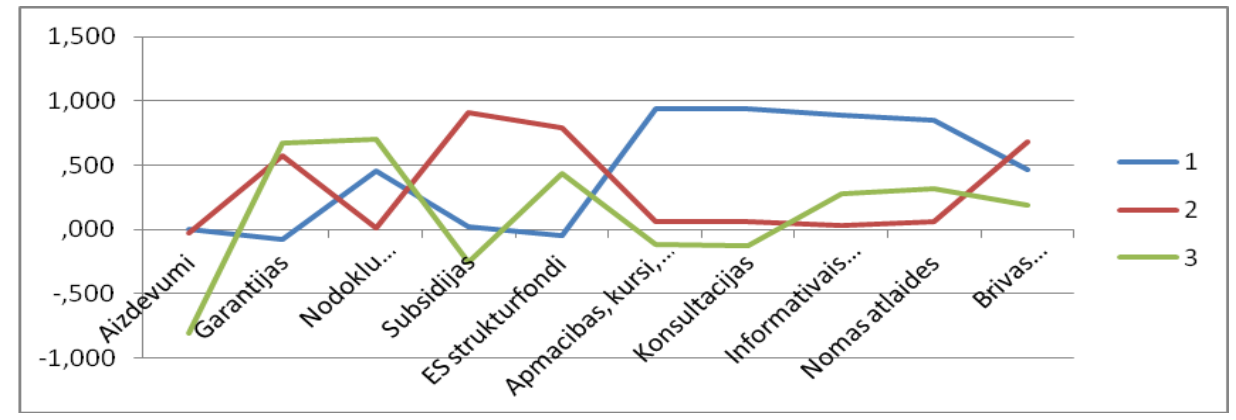

Figure 3. Coherences between groups of business support instruments

\section{Support tools impact on enterprise activity}

In order to find out what kind of business activities most significantly affects the usage of support resources, enterprises were divides in four factor groups.

As it is visible from statistical data analysis (Table 4.), it is possible to divide all enterprises in four groups; coherences between components in each group are marked bold.

Group 1 considers that support instruments influences increase of income, productivity, added value and wage, but decrease of labor force rotation. In this group dominates the reliance on income and benefits of productivity increase from added value. This group can be described as group of added value.

Group 2 regards that support instruments affects development of human resource abilities, creation of new work places, which provides technology and innovation development and increases corporate social responsibility and the increase of added value. For this group essential could be support instruments in human capital, evolvement of abilities, then innovations by increasing added value could be provided. Improvement of personnel abilities is essential. This group can be described as innovative, which will have its competitiveness advantages.

Group 3 deems that support instruments for "green product" creation will ensure also contamination decrease, followed by cost decrease. Consequently, "green products" are not only environment friendly, but also financially beneficial. This group can be described as business group of sustainable development, since the method to become competitive is decrease of contamination and increase of social worker responsibility. This factor is very essential, in order to earn business support for own enterprise, since they reflect the most important evaluation criterion for sustainable business.

Group 4 is concerned only about performance optimization, and this group can be described as profitdriven group.

Table 4. Impact of support instruments on enterprises activities in factor analysis

\begin{tabular}{|l|r|r|r|r|}
\hline \multicolumn{1}{|c|}{ Criterion } & \multicolumn{3}{c|}{ Components } \\
\cline { 2 - 5 } & 1 & 2 & \multicolumn{1}{c|}{3} & \multicolumn{1}{c|}{4} \\
\hline Income increase & $\mathbf{7 5 4}$ &, 271 &, 040 &, 454 \\
Cost reduction &, 359 &, 070 & $\mathbf{7 8 3}$ &, 261 \\
Productivity increase & $\mathbf{, 0 3}$ &, 401 &, 186 &,- 025 \\
Increase of added value &, 649 & $\mathbf{, 6 6 2}$ &, 070 &,- 032 \\
Creation of new work places &, 292 & $\mathbf{, 9 0 0}$ &, 107 &, 200 \\
Development of human resource abilities &, 475 & $\mathbf{, 7 1 7}$ &, 116 &, 382 \\
Wage increase & $\mathbf{6 3 8}$ &, 349 &, 234 &, 488 \\
Increase of export and competitiveness ability &, 544 &, 534 &, 397 &,- 117 \\
Decrease of labor force rotation & $\mathbf{9 2 4}$ &,- 083 &, 234 &, 041 \\
Performance optimization &, 057 &, 171 &, 100 & $\mathbf{, 8 9 2}$ \\
"Green product" creation &,- 029 &, 414 & $\mathbf{, 7 5 4}$ &, 250 \\
Technology and innovation development &,- 095 & $\mathbf{, 7 4 5}$ &, 509 &, 125 \\
Contamination decrease &, 269 &, 151 & $\mathbf{, 8 6 8}$ &,- 149 \\
Increase of corporative social responsibility &, 186 & $\mathbf{, 6 7 2}$ &, 451 &, 326 \\
\hline
\end{tabular}

Extraction method: Principial component analiysis.

Rothation method: Warimax with Kaiser normalization.

Rotation converged in 13 iterations. 


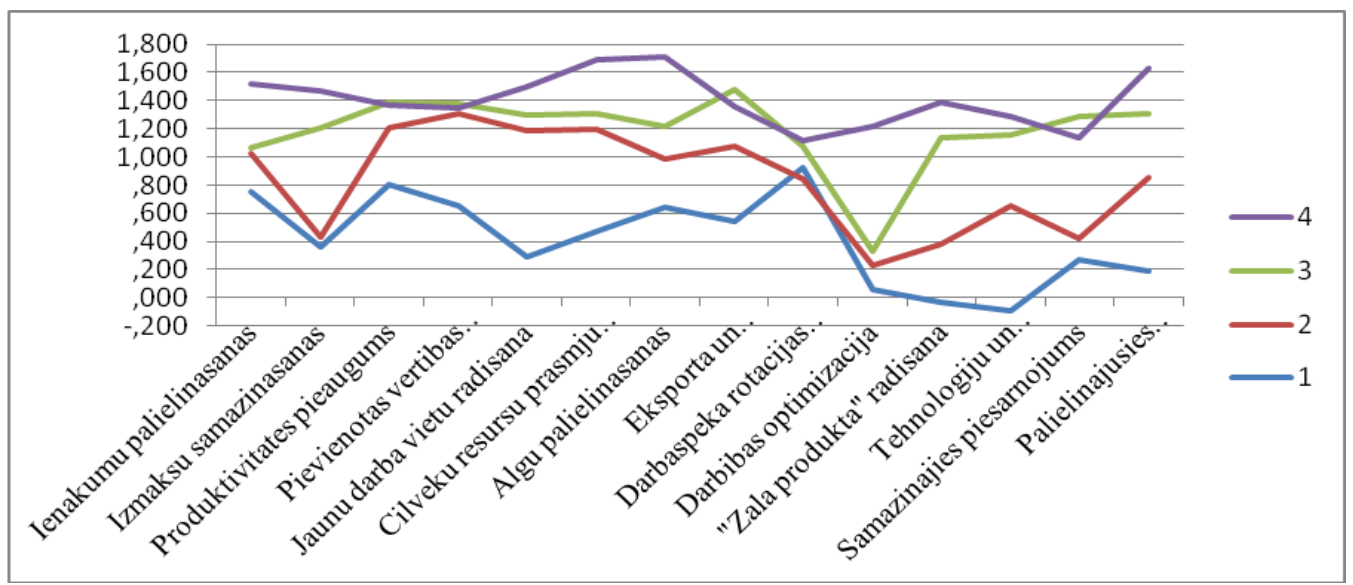

Figure 4. Coherence between support instrument impact on enterprise activities

As it is distinguished, three most popular support resources applied by organizations, leaves a proportionaly equivalent impact on different organization's aspects.

\section{Conclusions}

1. Basing on enterprise querying results, it is possible to conclude that the major influence on the company's sustainability, especially on the development of new company (period of activity is less than 1 year), is done by information and education support tools. Such groups does not have any limitations regarding supporting instruments, in its turn, other supporting tool availability and application is restricted for new companies.

2. The larger is the enterprise with longer period of activity, the less is the number of objective restrictions on available instruments and the larger is the variety of the applied supporting instruments.

3. The factor analysis used in the research is estimated as important method of determination of objective, correlative relations. The results thereof show the sustainability in itself, independently on the self-assessment of the enterprise.

4. Basing on the results of the factor analysis, it is possible to assume that as the sustainable development enterprises such ones can be considered, which are located in the innovative and sustainable development group (respectively, the group 2 and 3).

5. For assessment of effectiveness of environment management instruments and for making the corresponding decisions the authors recommend for State management institutions to use the query with the structure elaborated in this research, the following factor analysis and the corresponding regularity (at least once in two years).

\section{References}

1. Hackett, S.C.(2006). Environmental and Natural Resources Ecomomics. Theory, policy and the sustainable society. 3rd ed., M.E.Sharpe, Inc.

2. Strategic management tool. Sustainability Index. Latvia (2010-2011). /http://www.ilgtspejasindekss.lv/

3. Top 20 SSI-2010. Sustainable Society Foundation. (2012). http://www.ssfindex.com/results-2010/top-20-bottom20/

4. Data Details SSI-2010. Sustainable Society Foundation. (2010). http://www.ssfindex.com/ssi/data-details-ssi-2010/

5. Kosonen, K., Nicodèm, G.(2009). The role of fiscal instruments in environmental policy. Working Papers, University Libre de Bruxelles

6. Kumar.V., Aaker D.A., Day G.S. (2002). Essentials of Marketing Research, John Wily \& Sons, Inc., New York.

7. Yale Law School.(2011). Document collection. The Code of Hammurabi, http://avalon.law.yale.edu/ancient/hamframe.asp; Translated by L. W. King

8. Pollmill.com. (2011). Survey. http://apklausa.lt/private/forms/survey-of-business-support-in-lithuanian-latviancrosborder-region-lu-xaxzuj6 